\title{
EFEKTIVITAS HASIL BELAJAR SISWA DENGAN MENGGUNAKAN PENDEKATAN STUDENT CENTERED LEARNING (SCL) MELALUI DISCOVERY PADA MATA PELAJARAN TIK DI SMP LABORATORIUM UNP
}

\author{
Adlia Alfiriani ${ }^{1}$ \\ ${ }^{1}$ Dosen Pendidikan Informatika STKIP PGRI Sumbar \\ Alfi69600@yahoo.com
}

\begin{abstract}
ABSTRAK
Tujuan penelitian ini adalah untuk mengetahui efektivitas hasil belajar siswa dengan menggunakan pendekatan Student Centered Learning (SCL) melalui strategi discovery pada pembelajaran TIK kelas VIII SMP Pembangunan Laboratorium UNP. Metode penelitian yang digunakan yaitu kuantitatif kuasi eksperimen dengan populasi seluruh siswa kelas VIII tahun ajaran 2009/2010, sememtara sampel penelitian ini adalah kelas VIIIc (45 siswa) sebagai kelas eksperimen dan kelas VIIIb (45 siswa) sebagai kelas control. Dari hasil analisis data didapatkan hasil belajar rata-rata kelas eksperimen $(71,66)$ dan rata-rata kelas control $(62,53)$ dari data yang berdistribusi normal. Analisis dengan menggunakan uji t-tes didapatkan bahwa efektivitas hasil belajar siswa menggunakan pendekatan Student Centered Learning (SCL) melalui strategi Discovery dari pada pendekatan pembelajaran konvesional karna $t_{\text {hitung }}>t_{\text {tabel }}(4,83>1,98$. Ini berarti terdapat perbedaan hasil belajar antara kelas eksperimen dengan kelas kontrol sehingga dapat disimpulkan bahwa pendekatan SCL melalui strategi Discovery efektif terhadap hasil belajar TIK siswa kelas VIII SMP Pembengaunan Laboratoriium UNP.
\end{abstract}

Kata Kunci: Pendekatan SCL, Strategi Discovery, Hasil Belajar

\section{PENDAHULUAN}

Dalam penguasan Teknologi Informasi dan Komunikasi, siswa dituntut untuk mampu mengembangkan kecakapannya khusus di bidang komputer. Hal ini mengharuskan tenaga pendidik untuk merubah pendekatan yang biasa dilaksanakan yaitu pembelajaran berpusat pada guru (Teacher Centered Learning) menjadi pendekatan pembelajaran yang berpusat pada siswa (Student Centered Learning). Hal ini sesuai dengan tuntutan dunia masa depan dimana anak yang harus memiliki kecakapan berpikir dan belajar (thinking and learning skils). Kecakapan kecakapan tersebut diantaranya adalah kecakapan memecahkan masalah (problem solving), berpikir kritis (critical thinking), kolaborasi dan kecakapan berkomunikasi.
Semua kecakapan ini bisa dimiliki oleh siswa apabila guru mampu mengembangkan rencana pembelajaran yang berisi kegiatan-kegiatan yang menantang siswa untuk berpikir kritis dalam memecahkan masalah. Kegiatan yang mendorong siswa untuk bekerja sama dan berkomunikasi harus tampak dalam setiap rencana pembelajaran yang dibuatnya. Hal pertama yang dapat dilakukan untuk menggunakan pendekatan yang berpusat pada siswa adalah guru harus mampu meninggalkan kebiasaan memposisikan diri sebagai "pemain utama" dalam sinetron pembelajaran di kelas, sebaliknya jadikan siswa sebagai "pemeran utama", guru adalah "sutradara"nya. sebaiknya guru tidak menghabiskan waktu mengajarnya untuk menyampaikan materi, tapi berikan peluang kepada siswa untuk 
mengalami persitiwa belajar (tidak hanya menjadi "penonton" alias pendengar dan pencatat materi yang disampaikan).

Pada kenyataannya pembelajaran yang terjadi itu masih berpusat pada guru yang secara monoton menyampaikan materi pelajaran kemudian melakukan tanya jawab dan memberi tugas sehingga kelas masih terfokus pada guru sebagai sumber utama pengetahuan. Untuk itu diperlukan suatu pendekatan yang lebih mengaktifkan siswa dalam proses pembelajaran. Suatu pendekatan yang memberikan kesempatan kepada siswa untuk menjadi sentral dari proses pembelajaran yang akan dan sedang berlangsung. Dalam proses pembelajaran, siswa belajar dari pengalaman sendiri, mengkonstruksi pengetahuan, mendeskripsikan kembali pengetahuan yang ia punya dengan gaya bahasa dan cara yang sesuai dengan kemampuaanya, kemudian memberi makna pada pengetahuan itu. Melalui proses belajar yang mengalami sendiri, menemukan sendiri, secara individu maupun berkelompok seperti bermain sambil belajar, maka anak menjadi senang, sehingga dapat meningkatkan kreativitas dan hasil belajar, khususnya pada mata pelajaran TIK (Teknologi Informasi dan Komunikasi).

\footnotetext{
Siswa sekolah lanjutan pertama pada SMP Pembangunan Laboratorium UNP memiliki perbedaan satu sama lain, berbeda dalam minat, kemampuan, kesenangan, pengalaman dan cara belajar. Oleh karena itu kegiatan pembelajaran, waktu belajar, materi pembelajaran, alat belajar dan penilaian perlu beragam pula sesuai dengan karakteristik siswa. Proses pembelajaran perlu menempatkan siswa sebagai subjek belajar, artinya proses pembelajaran harus melibatkan siswa baik dalam penggunaan strategi pembelajaran, materi, menentukan sumber belajar dan penilaiaan sehingga dapat mendorong siswa untuk mengembangkan potensi yang ada dalam dirinya. Begitu pula
}

Dalam mata pelajaran TIK Siswa memiliki tingkat kemampuan yang berbeda, baik dari segi kreativitas maupun dari segi intelegensi dalam memahami materi yang disajikan. Berdasarkan fakta yang terjadi di lapangan biasanya guru melaksanakan proses pembelajaran yang bersifat konvensional, di mana guru tersebut masuk ke dalam kelas, menyampaikan materi, memberikan tugas kemudian menarik kesimpulan tentang apa yang sudah di pelajari. Hal ini selalu dilakukan guru pada setiap kali pertemuan dan membuat guru menjadi pusat dari proses pembelajaran. Maka dari itu untuk meningkatkan hasil belajar siswa, guru harus mampu melakukan berbagai inovasi-inovasi pembelajaran, salah satunya dengan memberi kesempatan kepada siswa untuk mengembangkan potensi-potensi yang ada dalam dirinya dan menjadikan siswa sebagai pusat dari proses pembelajaran yang sedang berlangsung. Tugas guru adalah menjadi seorang fasilitator untuk menciptakan suasana yang dapat dilakukan siswa dalam mengembangkan kemampuan-kemampuan yang ada dalam dirinya sehingga proses pembelajaran yang berlangsung benar-benar berpusat pada siswa dan tidak lagi terfokus pada penjelasan materi yang disampaikan oleh guru semata. Hal ini sesuai dengan kurikulum berbasis kompetensi yang diresmikan tahun 2004, yang mempertegas bahwa proses pembelajaran harus berpusat pada peserta belajar, pengajar bukan sebagai satu-satunya sumber belajar, melainkan berperan sebagai fasilitator, dinamisator dan motivator dalam pengajaran (Andoyo,2006). Dengan cara belajar yang aktif melalui pendekatan pembelajaran yang berpusat pada siswa diharapkan mampu meningkatkan hasil belajar siswa yang akan dijadikan tolak ukur dari keberhasilan dalam suatu pembelajaran.

\section{METODE PENELITIAN}

A. Jenis Penelitian

Bentuk penelitian ini adalah kuantitatif dengan Jenis penelitian eksperimen karena 


\section{Jurnal Edik Informatika E-ISSN : 2541-3716}

Penelitian Bidang Komputer Sains dan Pendidikan Informatika

V1.i2(7-17)

peneliti berusaha melihat dan mengungkapkan sejauhmana keefektivan penggunaan pendekatan student centered learning ( $\mathrm{scl}$ ) melalui metode pembelajaran inquiry terhadap hasil belajar siswa TIK dengan membandingkan hasil belajar dari kelas biasa. Pada rancangan penelitian ini, pada kelas exsperimen diberikan perlakuan dengan menggunakan pendekatan student centerd learning melalui metode pembelajaran inquiry, sedangkan pada kelas kontrol dilaksanakan pembelajaran konvensional atau pembelajaran teacher centered learning (tcl), selanjutnya pada kedua kelas dilakukan tes (posttest) yang sama. Hal ini terlihat dari tabel berikut ini :

Tabel 1. Tabel Rancangan Penelitian

\begin{tabular}{|c|c|c|}
\hline Kelas & Perlakuan & $\begin{array}{c}\text { Tes akhir } \\
\text { perlakuan }\end{array}$ \\
\hline Exsperimen & $\mathrm{X}$ & $\mathrm{T} 2$ \\
\hline Kontrol & - & $\mathrm{T} 2$ \\
\hline
\end{tabular}

Keterangan :

$\mathrm{X}_{1}=$ Pembelajaran dengan menggunakan

$S C L$ melalui metode pembelajaran inquiry

$\mathrm{T} 2=$ Tes yang diberikan diakhrir pokok bahasan

\section{B. Prosedur Penelitian}

Dalam penelitian ini akan dilakukan beberapa tahap yang terdiri dari :

\section{Tahap persiapan}

Pada tahap persiapan yang dilakukan adalah :

a. Menetapkan jadwal penelitian. b. Menetapkan konsep-konsep (pokok bahasan) untuk kelas VIII yang akan diteliti.

c. Membuat Rencana Pelaksanaan Program (RPP).

d. Mengakses beberapa situs di internet yang berkaitan dengan materi yang akan diajarkan.

e. Mempersiapkan tes akhir

\section{Tahap Pelaksanaan}

Pelaksanaan penelitian ini merupakan pemberian perlakuan selama proses pembelajaran. Perlakuan yang diberikan berbeda antara kelas exsperimen dengan kelas kontrol, seperti yang terlihat pada tabel berikut:

Tabel 2. Perlakuan yang diberikan pada kelas sampel

\begin{tabular}{|c|c|}
\hline Kelas eksperimen & Kelas kontrol \\
\hline-1 & -2 \\
\hline A. Pendahuluan & A. Pendahuluan \\
\hline $\begin{array}{l}2 . \quad \text { Guru memantau } \\
\text { kehadiran siswa melalui } \\
\text { ketua kelas }\end{array}$ & $\begin{array}{lr}1 . & \text { Guru } \\
\text { memeriksa } & \\
\text { kesiapan belajar } \\
\text { siswa dan } & \text { ruang } \\
\text { kelas } & \\
2 . & \text { Guru } \\
\text { memantau } & \\
\text { kehadiran } & \text { siswa } \\
\text { melalui } & \text { ketua } \\
\text { kelas } & \end{array}$ \\
\hline B. Kegiatan inti & B. Kegiatan inti \\
\hline $\begin{array}{l}\text { 1. Guru membagi siswa } \\
\text { kedalam } \quad \text { beberapa } \\
\text { kelompok } \\
\text { heterogen } \\
\text { 2. Guru menyampaikan } \\
\text { indikator } \\
\text { pembelajaran hari ini }\end{array}$ & $\begin{array}{l}1 . \quad \text { Guru } \\
\text { menyampaikan } \\
\text { tujuan pelajaran } \\
\text { yang akan dicapai } \\
2 . \quad \text { Guru } \\
\text { menerangkan } \\
\text { materi pelajaran }\end{array}$ \\
\hline
\end{tabular}




\section{Jurnal Edik Informatika E-ISSN : 2541-3716}

Penelitian Bidang Komputer Sains dan Pendidikan Informatika

V1.i2(7-17)

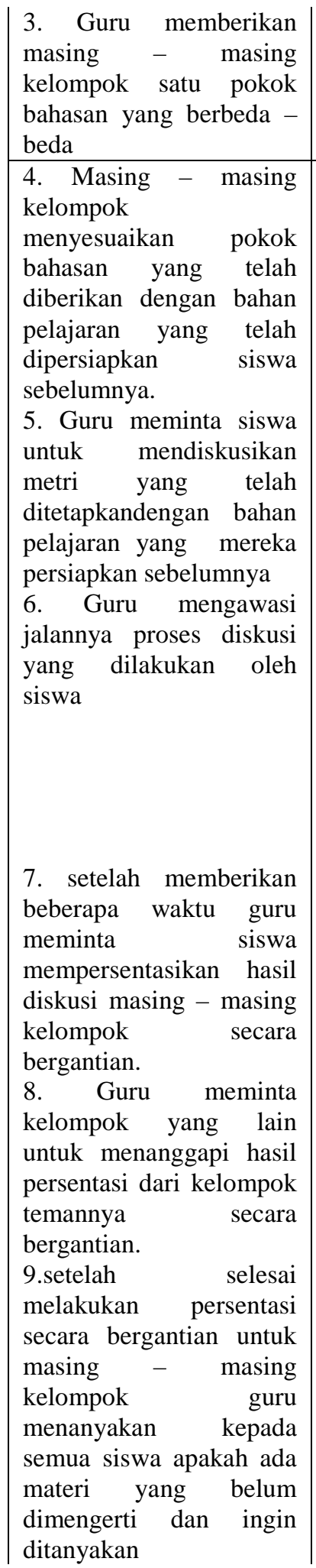

$\begin{array}{lr}\begin{array}{l}3 . \\ \text { menyimak }\end{array} & \text { Siswa } \\ \text { informasi } & \text { yang } \\ \text { diberikan } & \text { oleh } \\ \text { guru } & \\ \text { 4. Siswa diberikan } \\ \text { kesempatan untuk } \\ \text { menanyakan hal - } \\ \text { hal yang kurang } \\ \text { dipahami dan } \\ \text { dimengerti. }\end{array}$

dimengerti. $\begin{array}{lr}\text { 10. Guru meminta salah } \\ \text { satu dari masing - } \\ \text { masing } & \text { anggota } \\ \text { kelompok } & \text { untuk } \\ \text { menyimpulkan } & \text { materi } \\ \text { pelajaran } & \end{array}$

C. Kegiatan Penutup

1. Guru memberikan Post tes untuk melihat tingkat pemahaman siswa.

2. Guru meminta siswa untuk mempersiapkan bahan pelajaran untuk pertemuan selanjudnya sebagai tugas rumah

C. Kegiatan
Penutup
1. Guru
menyimpulkan
materi pelajaran
hari ini.
$2 . \quad$ Guru
memberikan tes
diakhir pelajaran
untuk mengetahui
tingkat
pemahaman siswa
terhadap pelajaran
hari ini.

\section{Tahap Evaluasi}

Tahap Evaluasi di perlukan untuk mengatahui hasil belajar yang telah dicapai siswa. Evaluasi dilakukan dengan memberikan tes pada akhir penelitian terhadap kedua kelas sampel. Evaluasi terdiri dari 40 butir soal dalam bentuk pilihan ganda dengan 4 alternatif jawaban.

\section{Populasi dan Sampel}

\section{Populasi}

Sesuai dengan masalah yang diteliti, maka populasi penelitian ini adalah seluruh siswa kelas VIII SMP Pembangunan Laboratorium UNP yang belajar mata pelajaran TIK. Jumlah siswa kelas VIII SMP Pembangunan Laboratorium UNP adalah 182 orang dan seluruh siswa wajib mengikuti mata pelajaran TIK. Dari 182 orang siswa dibagi ke dalam 4 kelas yaitu kelas VIIIa yang terdiri dari 46 siswa, kelas VIIIb yang terdiri dari 45 siswa, Kelas VIIIc 45 orang dan kelas VIIId terdiri dari 43 siswa.

2. Sampel 


\section{Jurnal Edik Informatika E-ISSN : 2541-3716}

Penelitian Bidang Komputer Sains dan Pendidikan Informatika

V1.i2(7-17)

Berdasarkan pada kebutuhan penelitian ini, maka diperlukan dua kelompok siswa sebagai sampel, yaitu satu kelas untuk kelas eksperimen dan satu kelas lainnya untuk kelas kontrol. Teknik pengambilan sampel pada penelitian ini adalah dengan menerapkan teknik Purposive Random Sampling yaitu sampel yang diambil berdasarkan maksud dan tujuan dengan pertimbangan kriteria-kriteria tertentu. Dengan alasan sampel dianggap mempunyai kemampuan siswa yang sama, belajar pada hari yang sama, dengan guru yang sama dan sarana prasarana yang sama.

Dengan demikian kelas yang dipilih sebagai sampel adalah kelas VIIIc dan VIIIb seperti tabel 4 di bawah ini.

Tabel 4. Jumlah Siswa dan Jadwal Belajar di kelas VIII di SMP Pembangunan Laboratorium UNP

\begin{tabular}{|c|c|c|c|c|}
\hline \multirow{2}{*}{ No } & \multirow{2}{*}{ Kclas } & .Jumlah & \multirow{2}{*}{ Jadwal Bclajar } & \multirow{2}{*}{ Sampcl } \\
\hline & & Siswa & & \\
\hline 1 & VIllet & 46 & Jum'al 10.15-11-35 & - \\
\hline 2 & VIIIb & 45 & Jum'at 08.15-09.55 & $\begin{array}{l}\text { Kelas } \\
\text { Kontinl }\end{array}$ \\
\hline 3 & Viilie & 45 & Rabu 07.15-08.20 & $\begin{array}{l}\text { Kulas } \\
\text { Exsperimen }\end{array}$ \\
\hline 4 & vilie" & 43 & Kabu 08.20-09-55 & - \\
\hline & Jumlah & 182 & & \\
\hline
\end{tabular}

Sumber : Tata Usaha SMP Pembangunan Laboratorium UNP

\section{Jenis dan Sumber Data}

\section{Jenis Data}

Jenis data dalam penelitian ini adalah data primer yaitu data langsung yang didapat dari data aslinya, data nilai hasil belajar siswa yang didapatkan dari hasil tes/evaluasi yang dilakukan guru TIK kelas VIII SMP Pembangunan Laboratorium UNP.

\section{Sumber Data}

Sumber data dalam penelitian ini adalah guru mata pelajaran TIK dan siswa kelas

\section{SMP Pembangunan Laboratorium UNP.}

\section{E. Teknik dan alat pengumpulan data}

1. Teknik pengumpulan data

Teknik pengumpulan data merupakan cara yang digunakan peneliti dalam mengumpulkan data. Dalam penelitian pendidikan teknik pengumpulan data adalah melalui observasi, quistioner, interviw, tes, sosiometri, dokumenter dan sebagainya.

\section{Alat Pengumpulan data}

Alat yang digunakan untuk mengumpulkan data dalam penelitian ini adalah tes yang diberikan pada kelas sampel yaitu kelas VIIIc sebagai kelas eksperimen yang menggunakan pendekatan student centered learning melalui metode pembelajaran inquiry dan kelas VIIIb sebagai kelas kontrol yang menggunakan pendekatan teacher centered learning yang sesuai dengan materi pelajaran yang diberikan selama perlakuan berlangsung dan dilakukan diakhir pertemuan. Agar didapatkan tes yang benarbenar valid, soal tes diseleksi terlebih dahulu oleh guru bidang studi TIK SMP Pembangunan Laboratorium UNP dan mengalami dua kali revisi/perbaikan sebelum di berikan ujian kepada siswa.

\section{F. Teknik Analisis Data}

Analisis terhadap data penelitian bertujuan untuk menguji kebenaran hipotesis yang diajukan dalam penelitian. Teknik analisis data yang digunakan dalam penelitian ini adalah analisis perbedaan dua rata-rata dengan terlebih dahulu melakukan uji normalitas dan uji homogenitas.

1. Uji normalitas

Uji normalitas bertujuan untuk melihat apakah sampel berdistribusi normal / tidak. Untuk menguji normalitas digunakan uji 


\section{Jurnal Edik Informatika E-ISSN : 2541-3716}

Penelitian Bidang Komputer Sains dan Pendidikan Informatika

V1.i2(7-17)

lilifors seperti yang dikemukakan oleh Syafril (2000) dengan langkah - langkah sebagai berikut :

a. Urutkan data dari yang terkecil sampai yang terbesar

b. Untuk $\mathrm{Z}_{\mathrm{i}}$ untuk setiap data dengan menggunakan rumus sebagai berikut :

$$
Z_{i=\frac{x-x}{S}}
$$

$$
\text { Ket } \begin{aligned}
: & x=\text { data yang dicari } Z_{i} \text { nya } \\
x & =\text { nilai rata }- \text { rata dari sampel } \\
& s=\text { Simpangan baku }
\end{aligned}
$$

c. Hitung $\mathrm{f}\left(\mathrm{Z}_{\mathrm{i}}\right)$ untuk setiap data yang sudah dibakukan tersebut dengan mempedomani data distribusi normal baku dengan cara yaitu :

1) Jika $Z_{i}$ mempunyai angka baertanda negative (-) lihat angka yang sejajar dengan angka $\mathrm{Z}_{\mathrm{i}}$ pada table kemudian hitung 0,5 angka tersebut.

2) Jika $Z_{i}$ bertanda positif $(+)$, maka $f$ $\left(Z_{i}\right)$ adalah 0,5 ditambah angka dalam daftar yang sejajar dengan nilai $Z_{i}$

d. Hitung $S\left(z_{i}\right)$ untuk setiap data dengan cara membagi nomor urut dengan jumlah data atau sampel

catt : Jika 2 buah data mempunyai nilai yang sama, maka $\mathrm{S}\left(\mathrm{z}_{\mathrm{i}}\right)$ sama untuk kedua sampel tersebut yaitu nomor urut terakhir dari data yang sama itu dibagi dengan jumlah sampel atau $n$.

a. Hitung selisih $\mathrm{f}\left(\mathrm{z}_{\mathrm{i}}\right)$ dengan $\mathrm{s}\left(\mathrm{z}_{\mathrm{i}}\right)$ untuk setiap data

b. Ambil angka yang paling besar dari selisih $\mathrm{f} \quad\left(\mathrm{z}_{\mathrm{i}}\right)$ dengan $\mathrm{s} \quad\left(\mathrm{z}_{\mathrm{i}}\right)$ dan dibandingkan dengan nilai table sesuai dengan jumlah data. Jika harga $f\left(z_{i}\right)-s$ $\left(\mathrm{z}_{\mathrm{i}}\right)$ lebih besar dari nilai table berarti data tidak normal dan jika harga $\mathrm{f}\left(\mathrm{z}_{\mathrm{i}}\right)$ $\mathrm{s}\left(\mathrm{z}_{\mathrm{i}}\right)$ lebih kecil dari nilai table maka, berarti data berdistribusi normal. Kalau $\mathrm{n}>30$ nilai kritis $\dot{\alpha} 0,05$ adalah 0,886

\section{Uji Homogenitas}

Uji homogenitas bertujuan untuk melihat apakah kedua sampel dengan langkah - langkah sebagai berikut seperti yang dikemukakan oleh Nana Sudjana (1996 : 250):

a. Mencari varians masing - masing kelompok data, kemudian dihitung harga $\mathrm{F}$ dengan rumus $\mathrm{F}=\mathrm{S}_{1}{ }^{2}$

$$
\mathrm{S}_{2}^{2}
$$

Ket : $\quad \mathrm{F}=$ Varians kelompok data $\mathrm{S}_{1}{ }^{2}=$ Varians hasil tes kelompok exsperimen $\mathrm{S}_{2}{ }^{2}=$ Varians hasil tes kelompok kontrol

b. Bandingkan harga $F_{\text {hitung }}$ dengan $F_{\text {tabel }}$ yang terdapat dalam daftar distribusi $F$ pada taraf signifikan 0,05 dan derajad kebebasan pembilang $\mathrm{n}-1$ atau $\mathrm{dk}=(\mathrm{n}$ 1)(n-1). Jika $F_{\text {hitung }}$ lebih kecil dari $F_{\text {tabel }}$ berarti kedua kelompok sampel memiliki varians yang homogen, sebaliknya jika $F_{\text {hitung }}$ lebih besar dari $\mathrm{F}_{\text {tabel }}$ berarti kedua kelompok sampel mempunyai varians yang heterogen.

\section{Uji t tes}

Untuk melihat tingkat singnifikan antara kelas eksperimen dengan kelas kontrol dengan rumus, seperti ang diungkapkan oleh Syafril (2000 : 39) sebagai berikut :

$$
\mathrm{t}=\frac{x_{1}-\underline{x}_{2}}{\sqrt{\frac{S D_{1}^{2}}{N_{1}-1}+\frac{S D_{2}^{2}}{N_{2}-1}}}
$$

Keterangan:

$$
\begin{aligned}
& \overline{x_{1}} \quad=\text { Skor rata-rata kelas Eksperimen } \\
& \overline{x_{2}} \quad=\text { Skor rata-rata kelas Kontrol } \\
& \mathrm{N}_{1} \quad=\text { Jumlah siswa pada Eksperimen }
\end{aligned}
$$




\section{Jurnal Edik Informatika E-ISSN : 2541-3716}

Penelitian Bidang Komputer Sains dan Pendidikan Informatika

V1.i2(7-17)

$\mathrm{N}_{2} \quad=$ Jumlah siswa pada kontrol

$\mathrm{SD}_{1}{ }^{2}=$ Kuadrat standard kelas Eksperimen

$\mathrm{SD}_{2}{ }^{2}=$ Kuadrat standart kelas Kontrol

\section{HASIL PENELITIAN DAN PEMBAHASAN}

\section{A. Deskripsi Data}

Berdasarkan penelitian yang telah di lakukan pada kedua kelas sampel, diperoleh data tentang hasil belajar siswa. Data tersebut diperoleh dari tes akhir pada kegiatan penelitian yang diberikan berbentuk tes objektif dengan empat alternatif jawaban dan jumlah soal yang disajikan adalah 40 butir soal yang lebih jelasnya dapat dilihat pada lampiran.

Hasil analisis jawaban siswa pada kegiatan tes akhir, diperoleh data hasil belajar yang dapat dari nilai tes siswa. yang dapat dilihat pada tabel 5 .

Tabel 5. Nilai rata-rata, Simpangan baku dan Varians Kelas Eksperimen dan Kelas Kontrol

\begin{tabular}{|l|c|c|c|c|}
\hline \multicolumn{1}{|c|}{ Kelas } & $\mathbf{N}$ & $\overline{\mathbf{X}}$ & $\mathbf{S}$ & $\mathbf{S}^{\mathbf{2}}$ \\
\hline Eksperimen & 45 & 71,66 & 9,99 & 99,86 \\
\hline Kontrol & 45 & 63.53 & 7,26 & 58,85 \\
\hline
\end{tabular}

Keterangan :

$$
\begin{array}{ll}
\frac{\mathrm{n}}{X} & =\text { Jumlah anggota sampel } \\
\mathrm{S} & =\text { Nilai rata-rata } \\
\mathrm{S}^{2} & =\text { Variansangan baku }
\end{array}
$$

Berdasarkan Tabel. 5 dapat dilihat bahwa sampel yang menggunakan pendekatan Student Centered Learning ( $\mathrm{scl}$ ) melalui metode pembelajaran inquiry memiliki rata - rata 71,66 dengan nilai tertinggi 90 dan nilai terendah 50, sedangkan nilai rata - rata pada kelompok kontrol yang masih menggunakan pendekatan pembelajaran konvensional/TCL 62,53 dengan nilai tertinggi 82 dan nilai terendah 50 .

Penelitian ini dilakukan di SMP Pembangunan Laboratorium UNP terhadap siswa VIII yang terdaftar pada tahun pelajaran 2009/2010, dimana kelas yang jadi sampel adalah kelas VIIIc (eksperimen) yang menggunakan pendekatan SCL melalui metode pembelajaran inquiry dan kelas VIIIb (kontrol) yang menggunakan pendekatan TCL pada mata pelajaran TIK, kemudian kedua kelas sampel diberikan tes akhir dengan bentuk dan jumlah soal yang sama sehingga didapat hasil dari penelitian ini. Deskripsi data penelitian dapat dilihat sebagai berikut:

1. Distribusi data kelas eksperimen dengan menggunakan pendekatan student centered learning melalui metode pembelajaran inquiry

Dari hasil tes yang diberikan kepada kelas eksperimen maka diperoleh skor, dimana

\begin{tabular}{|c|c|c|c|c|c|}
\hline No. & $\begin{array}{c}\text { Interval } \\
\text { Kelas }\end{array}$ & $\mathbf{F}$ & $\begin{array}{c}\text { Tepi } \\
\text { Interval } \\
\text { Kelas }\end{array}$ & Persentase & $\begin{array}{c}\text { Titik } \\
\text { Tengah }\end{array}$ \\
\hline 1 & $16-50$ & 2 & $\begin{array}{c}15,5- \\
50.5\end{array}$ & $1,1 \%$ & 18 \\
\hline 2 & $51-55$ & 0 & $\begin{array}{c}50,5- \\
55,5\end{array}$ & 0 & 53 \\
\hline 3 & $56-60$ & 3 & $\begin{array}{c}55,5- \\
60,5\end{array}$ & $6,6 \%$ & 58 \\
\hline 4 & $61-65$ & 7 & $\begin{array}{c}60,6- \\
65,5\end{array}$ & $15.5 \%$ & 63 \\
\hline 5 & $\begin{array}{ll}66 & 70\end{array}$ & 8 & $\begin{array}{c}65,5 \\
10,5\end{array}$ & $17,7 \%$ & 68 \\
\hline 6 & $71-75$ & 7 & $\begin{array}{c}70,5- \\
75.5\end{array}$ & $15,5 \%$ & 73 \\
\hline 7 & $76-80$ & 6 & $\begin{array}{c}75.5- \\
80.5\end{array}$ & $13.3 \%$ & 78 \\
\hline 8 & $81-85$ & 7 & $\begin{array}{c}86.5- \\
85,5\end{array}$ & $15,5 \%$ & 83 \\
\hline 9 & $86 \quad 90$ & 5 & $\begin{array}{l}85,5- \\
90,5\end{array}$ & $11,1 \%$ & 88 \\
\hline & Jumlah & 45 & & $100 \%$ & \\
\hline
\end{tabular}
skor tersebut di kelompokkan kedalam interval kelas sebagai berikut :

Tabel 6. Distribusi Data Kelas Eksperimen

13 Diterbitkan Oleh Program Studi Pendidikan Informatika STKIP PGRI Sumbar 
Berdasarkan data yang terkumpul seperti dalam tabel diatas skor akhir siswa kelas eksperimen cukup bervariasi dapat dilihat pada grafik histogram berikut:

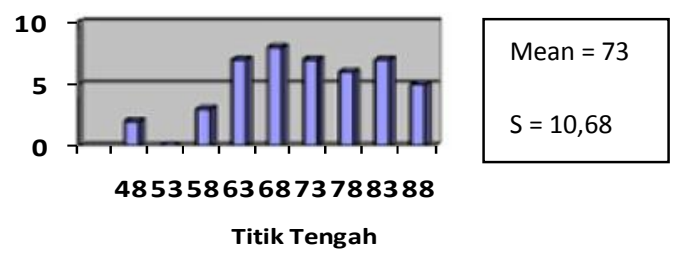

Gambar 2. Histogram distribusi nilai rata rata kelas eksperimen

2. Distribusi data kelas kontrol dengan menggunakan pendekatan Teacher Centered Learning

Dari hasil tes yang diberikan kepada kelas kontrol maka diperoleh skor, dimana skor tersebut di kelompokkan kedalam interval kelas sebagai berikut :

Tabel 7. Distribusi Data Kelas Kontrol

\begin{tabular}{|c|c|c|c|c|c|}
\hline No. & $\begin{array}{c}\text { Interval } \\
\text { Kelas }\end{array}$ & $\mathbf{F}$ & $\begin{array}{c}\text { Tepi } \\
\text { Interval } \\
\text { Kelas }\end{array}$ & Persentase & $\begin{array}{c}\text { Titik } \\
\text { Tengah }\end{array}$ \\
\hline 1 & $46-50$ & 4 & $\begin{array}{c}45,5- \\
50,5\end{array}$ & $8, / \%$ & 48 \\
\hline 2 & $51-55$ & 10 & $\begin{array}{c}50,5- \\
55,5\end{array}$ & $22 \%$ & 53 \\
\hline 3 & $56-60$ & 7 & $\begin{array}{c}55,5- \\
60,5\end{array}$ & $15 \%$ & 58 \\
\hline 4 & $61-65$ & 10 & $\begin{array}{c}60,5- \\
65,5\end{array}$ & $22 \%$ & 63 \\
\hline 5 & $66-70$ & 9 & $\begin{array}{c}65,5- \\
70,5\end{array}$ & $20 \%$ & 68 \\
\hline 6 & $71-75$ & 2 & $\begin{array}{c}70,5- \\
75,5\end{array}$ & $4,4 \%$ & 73 \\
\hline 7 & $76-80$ & 2 & $\begin{array}{c}75,5- \\
80,5\end{array}$ & $4,4 \%$ & 78 \\
\hline 8 & $81-85$ & 1 & $\begin{array}{c}81,5 \\
85,5\end{array}$ & $2,2 \%$ & 83 \\
\hline
\end{tabular}

Berdasarkan data yang terkumpul seperti dalam tabel di atas nilai akhir siswa kelas kontrol cukup bervariasi. Dapat dilihat pada grafik histogram sebagai berikut:

\section{B. Analisis Data.}

1. Uji Normalitas

Data tes akhir kelas eksperimen dan kelas kontrol diolah untuk menentukan uji normalitas. Pada uji normalitas ini digunakan uji Liliefors seperti yang dikemukakan pada teknik analisis data. Analisis normalitas pada kelas eksperimen dan kelas kontrol di kemukakan pada lampiran. Berdasarkan uji normalitas kelas eksperimen dan kelas kontrol di peroleh harga $\mathrm{L}_{0}$ dan $\mathrm{L}_{\mathrm{t}}$ pada taraf nyata 0,05 untuk $n>30$ seperti pada Tabel 8 .

Tabel 8.Hasil Uji Normalitas Kelas Eksperimen Dan Kelas Kontrol

\begin{tabular}{|l|c|c|c|c|}
\hline \multicolumn{1}{|c|}{ Kelas } & $\mathbf{N}$ & $\mathbf{A}$ & $\mathbf{L}_{\mathbf{0}}$ & $\mathbf{L}_{\mathbf{t}}$ \\
\hline Eksperimen & 45 & 0,05 & 0,046 & 0,132 \\
\hline Kontrol & 45 & 0,05 & 0,026 & 0,132 \\
\hline
\end{tabular}

Berdasarkan Tabel 8 terlihat bahwa kedua kelas eksperimen dan kelas kontrol memiliki $\mathrm{L}_{0}<\mathrm{L}_{\mathrm{t}}$, berarti data kedua kelas sampel berdistribusi normal. (Lengkapnya lihat lampiran 6).

\section{Uji Homogenitas}

Menentukan kelas eksperimen dan kelas kontrol memiliki varians yang homogen atau tidak maka di lakukan uji F.

Analisis sampel dikemukakan dalam lampiran 13. 
Tabel 9.Hasil Uji Homogenitas Kelas Eksperimen dan Kelas Kontrol

\begin{tabular}{|c|c|c|c|c|}
\hline Kelas & $\mathbf{A}$ & $\mathbf{F}_{\text {hitung }}$ & $\mathbf{F}_{\text {tabel }}$ & Kesimpulan \\
\cline { 1 - 4 } Eksperimen & \multirow{2}{*}{0,05} & 1,69 & 2,06 & Homogen \\
\hline Kontrol & & & & \\
\hline
\end{tabular}

Tabel 9 di atas tampak bahwa $F_{\text {hitung }}$ kelas eksperimen dan kelas kontrol lebih kecil dari $\quad F_{\text {tabel }}\left(F_{\text {hitung }}<\mathrm{F}_{\text {tabel }}\right)$, berarti kelas eksperimen dan kelas kontrol memiliki varians yang homogen. (lengkapnya lihat lampiran 8)

3. Uji-t

Berdasarkan uji normalitas dan uji homogenitas kelas eksperimen dan kelas kontrol, didapatkan bahwa kelas eksperimen dan kelas kontrol tersebut terdistribusi normal dan memiliki varians yang homogen. Untuk pengujian hipotesisnya digunakan uji-t

Langkah-langkah uji-t ini adalah sebagai berikut :

$$
\begin{aligned}
& \mathrm{t}=\frac{\overline{x_{1}}-\overline{x_{2}}}{\sqrt{\frac{S D_{1}^{2}}{N_{1}-1}+\frac{S D_{2}^{2}}{N_{2}-1}}} \\
& \mathrm{t}=\frac{71,66-62,53}{\sqrt{99,86}+\frac{58,85}{45-1}} \\
& \mathrm{t}=\frac{\sqrt{45,13}}{\sqrt{2,27}+1,38} \\
& \mathrm{t}=\frac{9,13}{\sqrt{3,65}} \quad \mathrm{dk}=\mathrm{n} 1+\mathrm{n} 2-2 \\
& \mathrm{t}=\frac{9,13}{1,91} \quad=45+45-2 \\
& \mathrm{t}=4,58 \quad \ldots-
\end{aligned}
$$

Hasil perhitungan dengan uji-t didapat harga $t_{\text {hitung }} 4,58$ dan pada taraf nyata 0,05 didapat harga $t_{\text {tabel }} 1,980$. Dengan demikian $t$ hitung $>\mathrm{t}$ tabel , maka dapat dikatakan bahwa hipotesis diterima atau $\mathrm{H}_{0}$ ditolak dan $\mathrm{H}_{\mathrm{i}}$ diterima. Dapat disimpulkan bahwa terdapat perbedaan yang berarti dari hasil belajar siswa antara kelas eksperimen yang diberi perlakuan dengan menggunakan pendekatan student centered learning ( $\mathrm{scl}$ ) melalui pembelajaran inquiry dalam proses pembelajaran dibandingkan dengan kelas kontrol melakukan proses pembelajaran dengan pendekatan konvensional. (lengkapnya lihat lampiran 9)

\section{Pembahasan}

Berdasarkan hasil tes akhir siswa, berupa soal yang diberikan pada kelas eksperimen dan kelas kontrol, maka diperoleh gambaran pada kelas eksperimen siswa yang mendapat nilai diatas KKM >65 berjumlah 36 orang siswa sedangkan siswa yang mendapat nilai dibawah KKM nilai $<65$ berjumlah 9 orang siswa. Sedangkan pada kelas kontrol siswa yang mendapat nilai diatas KKM >65 berjumlah 28 orang siswa (Lampiran). Dari analisis data yang telah dilakukan sebelumnya, dapat dilihat perbedaan yang signifikan antara kelas eksperimen yang menggunakan pendekatan pembelajaran yang berpusat pada siswa (scl) dibandingkan dengan kelas kontrol yang masih menggunakan pendekatan konvensional dalam melaksanakan proses pembelajaran, hal ini terlihat dari tingkat pemahaman materi dari siswa itu sendiri dan dibuktikan dengan banyaknya jumlah siswa yang tuntas atau nilainya diatas KKM pada kelas eksperimen sebanyak 36 orang siswa, sedangkan pada kelas kontrol hanya 19 orang siswa.

Hasil analisis data yang telah dilakukan bahwa $t_{\text {hitung }}$ sebesar 4,83 bibandingkan dengan $t_{\text {tabel, }}$ sebesar 1,98 dengan derajat kebebasan $\left(\mathrm{dk}=\mathrm{n}_{1}+\mathrm{n}_{2}\right)$, dengan demikian $t_{\text {hitung }}$ lebih besar dari $t_{\text {tabel }}$ yang berarti terdapat perbedaan yang signifikan terhadap hasil belajar siswa dengan menggunakan 
pendekatan student centered learning melalui metode pembelajaran inquiry dengan pembelajaran yang menggunakan pendekatan teacher centered learning, artinya “ Pendekatan pembelajaran Student centered Learning (SCL) melalui metode pembelajaran inquiry efektif dalam meningkatkan hasil belajar siswa kelas VIII pada mata pelajaran TIK di SMP Pembangunan Laboratorium UNP tahun ajaran 2009/2010, diterima. Dengan demikian pembelajaran dengan menggunakan pendekatan student centered learning ( $\mathrm{scl}$ ) melalui metode pembelajaran inquiry dianggap lebih baik dibandingkan dengan pendekatan konvensional. Penerapan pendekatan SCL dalam proses pembelajaran di kelas tidak hanya dilakukan oleh guru bidang studi TIK saja melainkan pendekatan SCL ini juga cocok diterapkan dalam mata pelajaran lain seperti sains, matematika, social dll.

Pada kelas eksperimen dapat dilihat bahwa hasil belajar lebih tinggi dibandingkan degan kelas kontrol. Pada kelas eksperimen selama melakukan penelitian atau 6 kali pertemuan siswa dilibatkan langsung dalam pelaksanaan pembelajaran baik dari segi pengadaan materi pembelajaran, medode penyampaiaan materi di kelas, evaluasi sampai pada menarik kesimpulan. hal ini juga sesuai dengan tututan pendidikan dimasa depan yaitu pembelajaran yang berpusat pada siswa atau yang lebih dikenal dengan Student Centered Learning $(S C L)$, yang mana proses pembelajaran lebih dititik beratkan pada keaktifan siswa. Pendekatan SCL ini juga dapat dilaksanakan dengan menggunakan beberapa strategi, salah satunya dengan menggunakan metode pembelajaran inquiry disini diartikan siswa harus mencari sendiri dari berbagai sumber mengenai materi materi pelajaran yang akan dipelajari.

Dengan diterapkannya pendekatan Student Centered Learning melalui metode pembelajaran inquiry dalam proses belajar mengajar di kelas dapat menjadikan siswa lebih berperan aktif dibandingkan guru. Suparno (1997) menyatakan bahwa " kegiatan belajar adalah kegiatan yang aktif, dimana pelajar membangun sendiri pengetahuaannya, pelajaran mencari arti sendiri dari yang mereka pelajari". Artinya siswa itu sendiri yang bertanggung jawab atas hasil belajarnya. Hal ini juga sesuai dengan peraturan pemerintah No.19 Tahun 2005 pada Bab IV pasal 19 yaitu : “ Proses pembelajaran pada satuan pendidikan diselenggarakan secara interaktif, inspiratif, menantang, memotivasi peserta didik untuk berpartisipasi aktif, serta memberikan ruang yang cukup bagi prakarsa, kreativitas dan kemandirian sesuai dengan bakat, minat dan perkembangan fisik serta psikologis peserta didik. Ini berarti pembelajaran yang didisain oleh guru itu harus menjadikan siswa sebagai subjek dari proses pembelajaran."

Dalam uraian ini pembahasan diatas dapat disimpulkan bahwa " Pendekatan Student Centered Learning (SCL) melalui metode pembelajaran inquiry mampu meningkatkan hasil belajar siswa pada mata pelajaran TIK dengan pokok bahasan identifikasi Program Microsoft Word kelas VIII di SMP Pembangunan Laboratorium UNP Padang".

\section{KESIMPULAN}

dalam penggunaan modul pembelajaran bilingual berbasis komputer pada pokok bahasan "Perangkat lunak pengolah kata" menunjukkan bahwa modul ini memiliki tingkat kepraktisan yang tinggi dalam artian mudah digunakan dalam proses pembelajaran. Sedangkan hasil dari uji keefektifan yang dilakukan terhadap 24

orang siswa kelas IV SD juga menunjukan bahwa modul pembelajaran bilingual berbasis komputer pada pokok bahasan "Perangkat lunak pengolah kata" memiliki tingkat keefektifan yang tinggi terhadap hasil belajar siswa. Hal ini dapat dilihat pada hasil belajar siswa yang sangat baik 
dari aspek pemahaman konsep (kognitif), dan keterampilan (psikomotor) setelah belajar dengan menggunakan modul pembelajaran bilibual berbasis komputer ini, sehingga modul ini dinyatakan efektif untuk pencapaian hasil belajar yang optimal baik dari aspek kognitif dan aspek psikomotor.

\section{DAFTAR PUSTAKA}

Arifin. Tina.2008. Pembelajaran Berbasis Student Centered Learning. www. Inparametetic.com.

Basuki, Sulistyo. 1998. Dasar-dasar Teknologi Informasi. Jakarta : Universitas Terbuka.

Depdiknas. 2003. Standar Kompetensi Mata Pelajaran TI dan K SMA dan Madrasah Aliyah. Jakarta : Depdiknas.

Gulo, W. 2002. Strategi Belajar Mengajar. Jakarta : Grasindo

Hadi, Sutrisno.1993. Statistik 2. Yogyakarta : Andi Offset

Hasan Iqbal.1990. Pokok - pokok Materi $\begin{array}{lll}\text { Statistik } \quad 1 \quad \text { (Statistik } & \text { 1 }\end{array}$ Deskriptif).Jakarta.Bumi Aksara.

S.B. Widyandani. 2008. Student Centered Learning.www.google.co.id (di akses tanggal 13 Februari 2008)

Sanjaya, Wina,2008. Startegi Pembelajaran Berorientasi Standar Proses Pendidikan. Jakarta. Kencana Prenada Media Group

Senat UNP. 2007. Buku Panduan Penulisan Tugas Akhir/Skripsi Universitas Negeri Padang. Padang : Universitas Negeri Padang.

Sudjana, Nana. 2005. Metoda \& Teknik Pembelajaran Partisipatif. Bandung : falah Production

Syafril.2000.Statistik Lanjutan : UNP Padang
Tim Dosen FIP. 2006. Bahan Ajar Belajar dan Pembelajaran. Padang : FIP.UNP.

Tim Pustaka Yustisia. 2008. Panduan Lengkap Kurikulum Tingkat Satuan Pendidikan. Yogyakarta : Pustaka Yustisia

Uno, Hamzah. 2007. Model Pembelajaan. Jakarta : Bumi Aksara

Yamin, Martinis \& Anshari, Bansu. 2008. Taktik Mengembangkan Kemampuan Individual Siswa. Jakarta : GP Press

Zelhendri Zen. 2007. Ringkasan Materi Perkuliahan Penelitian Kuantitatif. UNP. Padang 